\title{
THE 1.88 Ga OLD MÄNTYLÄ COMPLEX, CENTRAL FINLAND: EMPLACEMENT AND DEFORMATION OF MAFIC TO FELSIC PLUTONIC ROCKS AND ASSOCIATED Mo MINERALIZATION
}

\author{
MIKKO NIRONEN and KAI FRONT
}

NIRONEN, MIKKO \& FRONT, KAI, 1992. The 1.88 Ga old Mäntylä complex, central Finland: emplacement and deformation of mafic to felsic plutonic rocks and associated Mo mineralization. Bull. Geol. Soc. Finland, 64, Part 1, 75-90.

The Mäntylä complex is part of the extensive Central Finland Granitoid Complex. The intrusive sequence was established from contact relations as well as from structural and petrographic criteria. Metagabbros, occurring as narrow strips, are the oldest plutonic rocks. Quartz diorite varies from a fairly homogeneous rock to a migmatitic one with abundant xenoliths of supracrustal rocks. Porphyritic monzodiorite contains two small bodies of gabbro pegmatoid. Hypersthene granites, occurring as five small bodies, contain molybdenite in garnet-orthoclasite pockets and veins as well as in quartz veins. Biotite granite and monzogranite, the predominant rock type of the complex, are the most felsic rock types. The complex is surrounded by coarse-porphyritic granitoids except for the northern contact where highgrade gneisses prevail.

The supracrustal rocks were metamorphosed and deformed at least once before the emplacement of the plutonic rocks. A local $D_{a}-D_{d}$ deformational sequence was established in the complex. Penetrative $\mathrm{S}_{\mathrm{a}}$ foliation can be discerned in one of the hypesthene granite bodies. The prevailing, NW-WNW striking $S_{b}$ foliation occurs as a penetrative or spaced foliation in the plutonic rocks. $S_{c}$ spaced foliation and younger shear zones $\left(D_{d}\right)$ are encountered in restricted areas.

The emplacement of the Mäntylä complex started before $\mathrm{D}_{\mathrm{a}}$ with the intrusion of the metagabbros. The rest of the complex intruded during a short time interval, about 1886-1880 Ma ago. The quartz diorite and the monzodiorite were emplaced fairly contemporaneously. The hypersthene granites intruded after the quartz diorite, during and after $\mathrm{D}_{\mathrm{a}}$ deformation. The monzogranite and the coarse-porphyritic granitoids intruded during $D_{b}$. Possibly the forceful emplacement of the monzogranite pushed apart the previously closely arranged hypersthene granite bodies. This mechanism explains the differences in molybdenum mineralization between the hypersthene granite bodies at the present erosional level. The garnet orthoclasite was formed $1880 \mathrm{Ma}$ ago, during $\mathrm{D}_{\mathrm{c}}$ deformation. A small body of orbicular quartz diorite is slightly younger (1876 Ma) than the other rock types.

The petrography of the Mäntylä complex and the surrounding coarse-porphyritic granitoids indicates a relatively deep source area with dry conditions. Geochemical characteristics indicate that the rock types represent different source materials. Only the most evolved rocks, i.e. the hypersthene granites, the biotite granite and the monzogranite are possibly comagmatic. The geochemical diversity and the short time interval of emplacement indicates rapid crust-forming and differentiation processes in the early Proterozoic.

Key words: igneous rocks, complexes, granites, geochemistry, structural analysis, absolute age, emplacement, molybdenum ores, Proterozoic, Mäntylä, Viitasaari, Finland.

Mikko Nironen: Geological Survey of Finland, SF-02150 Espoo, Finland. Kai Front: Technical Research Centre of Finland, P.O. Box 108, SF-02151, Finland. 


\section{Introduction}

The geological history of the extensive Central Finland Granitoid Complex (CFGC) is yet unresolved although it is crucial considering the evolution of the whole Svecofennian crust. Detailed petrographic, structural and/or geochemical investigations of the rocks within the CFGC have been published only from a few small areas (Aho 1979, Nironen and Csongrádi 1984, Nurmi et al. 1984). The general characteristics of the granitoids of the CFGC have been presented by Front and Nurmi (1987). The majority of the rocks within the CFGC vary in composition from granite to quartz diorite, but there are also diorites, gabbros, and remnants of schist belts. The extent of the more mafic intrusive rocks and the schists is not known, but they probably are minor in volume. The U-Pb zircon ages of different intrusive rocks within the CFGC range around 1890-1880 Ma (Aho 1979, Nurmi et al. 1984, Huhma 1986).

The Mäntylä plutonic complex has been treated briefly by Nurmi et al. (1984). The complex is in the Viitasaari commune, near the northeastern margin of the CFGC, (Fig. 1). As in the CFGC as a whole, the composition of the intrusive rocks ranges from gabbro to prevailing granite. The complex has been repeatedly an exploration target because of molybdenum and copper showings found in the area.The complex is surrounded by coarse-porphyritic granitoids which occupy vast areas of the whole CFGC. Immediately north of the Mäntylä complex, there is a schist area within the CFGC, consisting of amphibolites, diopside amphibolites, hypersthene gneisses, garnet-cordierite-sillimanite gneisses and quartz-feldspar schists. Pillow structures found in the amphibolites indicate that at least the mafic rocks are volcanic in origin.

By means of contact phenomena and structural overprinting criteria, a relative age sequence can be established in the Mäntylä complex. The older rocks are multiply deformed while the younger ones are only slightly foliated. The mafic rocks are the oldest and the rocks become more felsic with decreasing age, but geochemical evidence indicates a complex origin and evolution for the granitoids. In this study, the emplacement sequence in the Mäntylä complex is considered by means of structural studies as well as (mainly) major element geochemistry.

\section{Intrusive series in the Mäntylä complex}

The Mäntylä complex consists of metagabbro, gabbro pegmatoid, monzodiorite, quartz diorite, hypersthene granite, biotite granite, and monzogranite. The metagabbros, the oldest igneous rocks in the complex, occur as irregularly shaped bodies within the granitoids (Fig. 1). They are usually massive, but also banded varieties occur, with alternating amphibole/pyroxene-rich and more plagioclase-bearing bands. Brecciating contacts were found between dark and more felsic massive varietes. Main constituents are plagioclase $\left(\mathrm{An}_{30-40}\right)$, hornblende, biotite, diopside, pale amphibole, and hypersthene.

The quartz diorite occurs as an elongate body in the western part of the complex. It is a smallto medium-grained, weakly foliated rock. Main constituents are plagioclase $\left(\mathrm{An}_{30}\right)$, quartz, hypersthene, biotite, and in places hornblende. The quartz diorite contains xenoliths of diopsidehornblende gneiss. The amount of xenoliths varies considerably: in the northern part the quartz diorite is fairly homogeneous but changes southwards to a schlieren-migmatitic rock in which tonalitic veins, subparallel to foliation, crosscut the gneiss. The diopside-hornblende gneiss may be correlated with the supracrustal rocks north of the complex.

The monzodiorite occurs as two elongate bodies in the northern part of the complex. The rock is porphyritic, with abundant plagioclase $\left(\mathrm{An}_{33-40}\right)$ phenocrysts $0.5-1.5 \mathrm{~cm}$ in size. The rock consists mainly of plagioclase, biotite, quartz, diopside, and in places cummingtonite as an alteration product of diopside. The rock is 


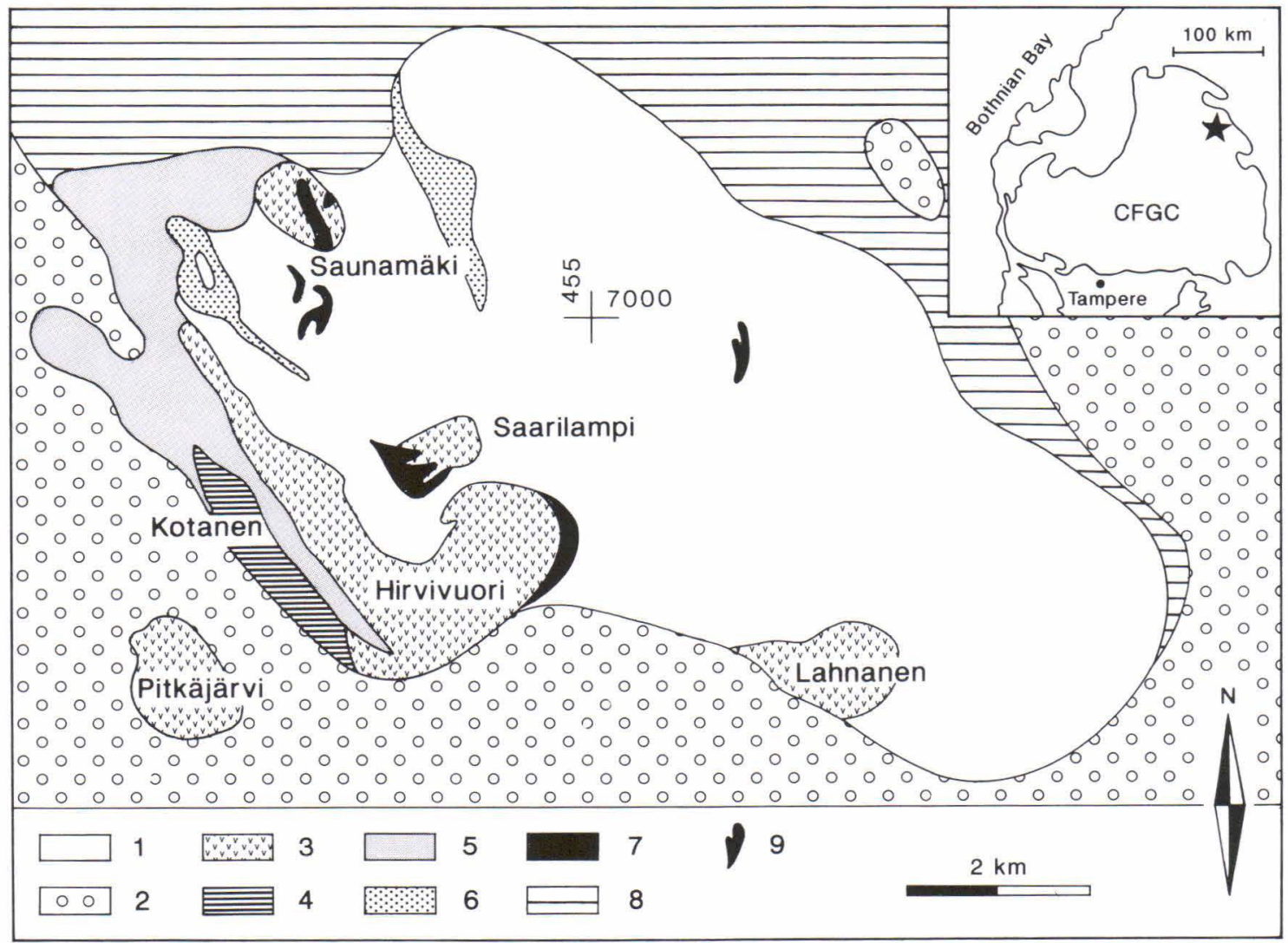

Fig. 1. Geological map of the Mäntylä complex and surrounding rocks. Modified from Nurmi et al. (1984). $1=$ monzogranite, 2 = coarse-porphyritic granite/granodiorite, $3=$ hypersthene granite/granodiorite, $4=$ biotite granite, $5=$ quartz diorite, $6=$ monzodiorite, $7=$ metagabbro, $8=$ supracrustal gneisses, $9=$ orbicular quartz diorite. Inset shows the setting of the complex within the Central Finland Granitoid Complex (CFGC), surrounded by schists and gneisses.

generally homogeneous, but in the marginal areas the monzodiorite contains enclaves of finegrained, mafic rock (possibly dike rock). The monzodiorite crosscuts the metagabbros, but the age relationship between the monzodiorite and the quartz diorite is unclear. Towards the contact to the quartz diorite, enclaves of biotite gneiss appear in the monzodiorite, and the rock is schollen-migmatitic at the contact. The biotite gneiss enclaves may be altered inclusions of quartz diorite.

Within the western monzodiorite there are two small bodies of gabbro pegmatoid with strongly variable grainsize (from $2 \mathrm{~mm}$ up to $4 \mathrm{~cm}$ ). Their contacts to the monzodiorite are in places sheared, in places gradating, and magmatic layering can be seen in the rock. The composition of the gabbro pegmatoid varies from leucogabbro to hornblendite; major constituents are hornblende, plagioclase $\left(\mathrm{An}_{40}\right)$, diopside, and pale amphibole as an alteration product of diopside.

The hypersthene granite occurs as five bodies. Their composition ranges from granodiorite to prevailing monzogranite. The hypersthene granite is medium-grained and usually massive or weakly foliated. Dark, roundish quartz grains and aggregates, 3-7 mm in diameter, are characteristic and give the rock a porphyritic appear- 
ance. Main constituents are plagioclase $\left(\mathrm{An}_{24-30}\right)$, quartz, and $\mathrm{K}$-feldspar. Hypersthene occurs as an accessory mineral. Biotite occurs as a brown type which forms symplectitic intergrowth texture with quartz, and as a green variety which is an alteration product of hypersthene. The hypersthene granite usually sharply crosscuts the metagabbros, but in places the contact is migmatitic. The granite at Hirvivuori contains fragments of quartz diorite. At Pitkäjärvi, the hypersthene granite contains abundant feldspar megacrysts, $4-25 \mathrm{~mm}$ in diameter. The megacrysts are concentrated in shear zones, and are possibly the result of metasomatic fluid flow.

At Hirvivuori, there is a marginal variety of the hypersthene granite which is characterized by a distinct, penetrative foliation. Because of intense foliation, the rock does not contain any dark quartz grains and aggregates. At the contact between the marginal type and the migmatitic diopside-hornblende gneiss (with quartz diorite as neosome), the diopside-hornblende gneiss has been altered into a garnet-biotite gneiss due to intrusion of the hypersthene granite. In places the neosome is garnet-bearing and granodioritic in composition. The width of the alteration zone is $100-150 \mathrm{~m}$.

There are small molybdenum mineralizations within the hypersthene granite at Lahnanen. Molybdenite occurs in considerable amounts in four small pockets and numerous veins of exceptional composition. This rock type is called garnet orthoclasite (Oivanen and Eskola 1972). The pockets are $3-20 \mathrm{~m}$ in length and $4-8 \mathrm{~m}$ in width (at present surface), and the veins are $15-70 \mathrm{~cm}$ in width and up to $30 \mathrm{~m}$ in length. The veins sharply crosscut the host rock whereas also gradating margins, a few $\mathrm{cm}$ in width, were observed in some pockets. The rock consists mainly of perthitic orthoclase $(70-90 \%)$ and almandine $(5-15 \%)$. Other minerals are $\mathrm{Fe}$ rich olivine, biotite, magnetite, quartz and oligoclase. Accessory minerals are zircon, apatite and spinel, the latter in association with magnetite and garnet. Serpentine, epidote and chlorite occur as alteration products of olivine and biotite. Molybdenite occurs as small aggregates. Pegmatite occurs in some pockets. Also nonmineralized garnet orthoclasite was met with. Molybdenite also occurs sporadically at the margins of dark bluish quartz veins in the hypersthene granites. Molybdenite-bearing quartz veins were observed at Lahnanen, Hirvivuori, and Saarilampi.

The biotite granite at Kotanen is mesoscopically similar to the hypersthene granite (i.e., dark quartz grains and aggregates), but the rock is somewhat smaller in grainsize and hypersthene is a rare mineral. Main constituents are plagioclase $\left(\mathrm{An}_{15-28}\right)$, quartz, $\mathrm{K}$-feldspar, and biotite. Biotite occurs as separate red-brown flakes as well as symplectitically intergrown with quartz, whereas a green variety is unexceptionally intergrown with quartz. There are three Cu-As showings within the biotite granite (see Nurmi et al. 1984). Another Cu-As showing is at the contact between the migmatitic hornblende gneiss and the marginal variety of the hypersthene granite at Hirvivuori. These small mineralizations are associated with silicification and K-feldspathization.

The reddish, medium- to coarse-grained monzogranite occupies most of the Mäntylä complex. The rock is usually equigranular, but in the center a porphyritic type prevails, with subhedral Kfeldspar megacrysts 5-20 mm in diameter. Main constituents are quartz, plagioclase $\left(\mathrm{An}_{18-29}\right)$, and $\mathrm{K}$-feldspar. Biotite is the only mafic mineral. Both sharp and gradational contacts between the monzogranite and the hypersthene granites were observed. In places there is a fine-grained (aplitic) marginal variety of the monzogranite at the contact against the hypersthene granitoid. The monzogranite as well as the hypersthene granites are crosscut by aplitic dikes. There is a small, elongate occurrence of orbicular quartz diorite in the center of the monzogranite.

The coarse-porphyritic granitoids surrounding the Mäntylä complex (and occupying a major part of the whole CFGC) are granodioritic to gra- 


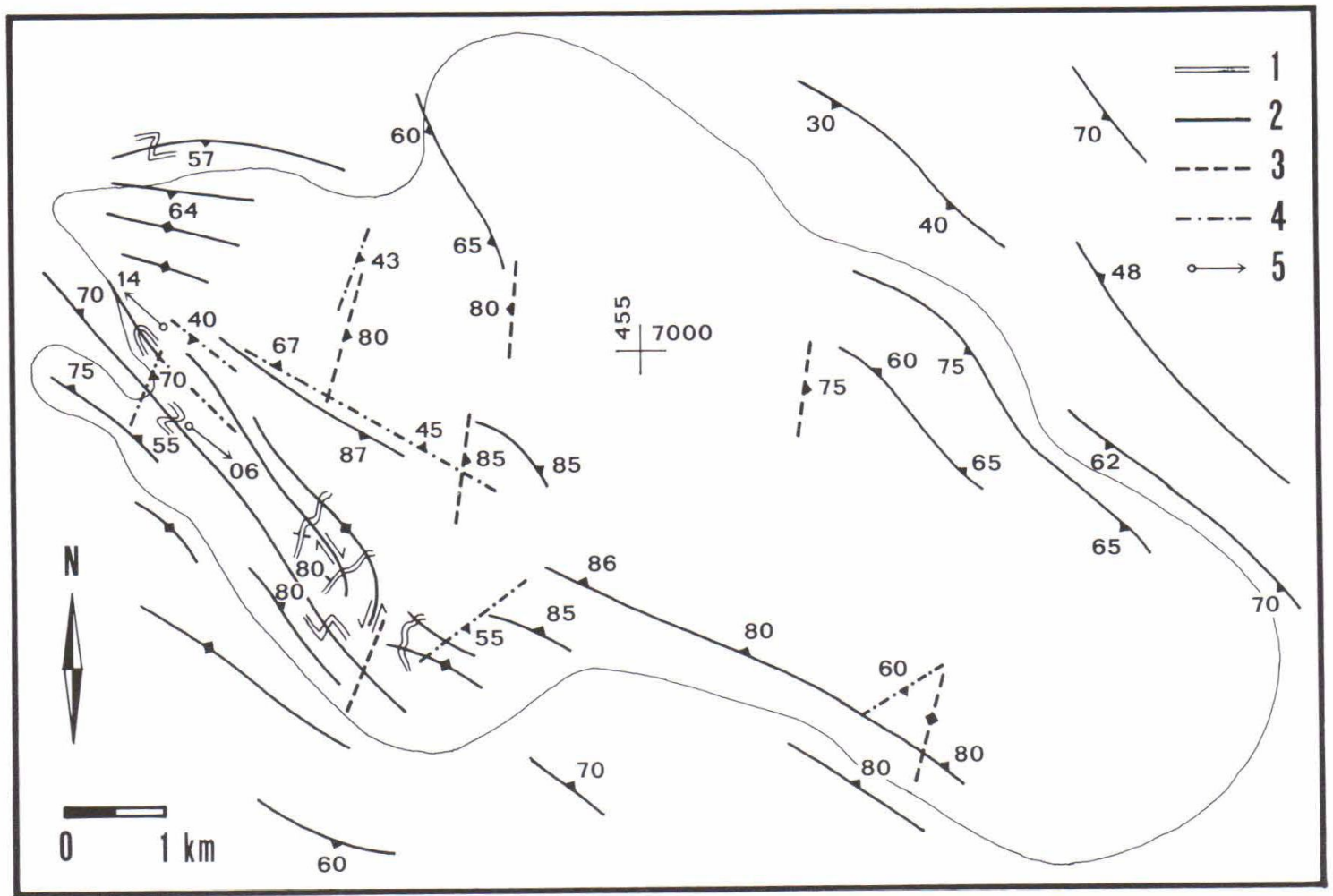

Fig. 2. Structural map of the Mäntylä complex and surrounding rocks. $1=\mathrm{S}_{\mathrm{a}}, 2=\mathrm{S}_{\mathrm{b}}, 3=\mathrm{S}_{\mathrm{c}}, 4=\mathrm{D}_{\mathrm{d}}$ shear zone, $5=$ $F_{b}$ fold axis.

nitic in composition. The granitic rocks are in the eastern and southeastern part of the study area. Up to $80 \%$ of the rock consists of large (diameter

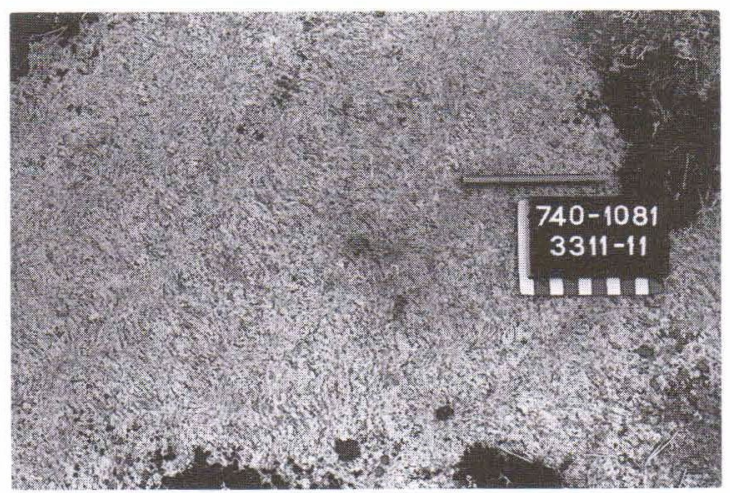

Fig. 3. $\mathrm{S}_{\mathrm{a}}$ foliation in hypersthene granite (marginal type), crenulated by $S_{b}$ foliation. Hirvivuori. Length of scale bar $10 \mathrm{~cm}$.
1 to $7 \mathrm{~cm}$ ), anhedral to subhedral feldspar megacrysts. In addition to $\mathrm{K}$-feldspar and plagioclase $\left(\mathrm{An}_{26-30}\right)$, quartz and biotite are the main constituents. Hypersthene occurs as an accessory mineral. Commonly the contact between the coarse-porphyritic granitoid and other igneous rocks is sheared. However, in places the coarse-porphyritic granitoid clearly crosscuts both the quartz diorite and the hypersthene granite. The contact between the monzogranite and the coarse-porphyritic granitoid is covered by soil.

\section{Structural sequence}

A deformational sequence of four episodes, $D_{a}-D_{d}$, was distinguished in the granitoids of the Mäntylä complex (Fig. 2). In addition, at least 


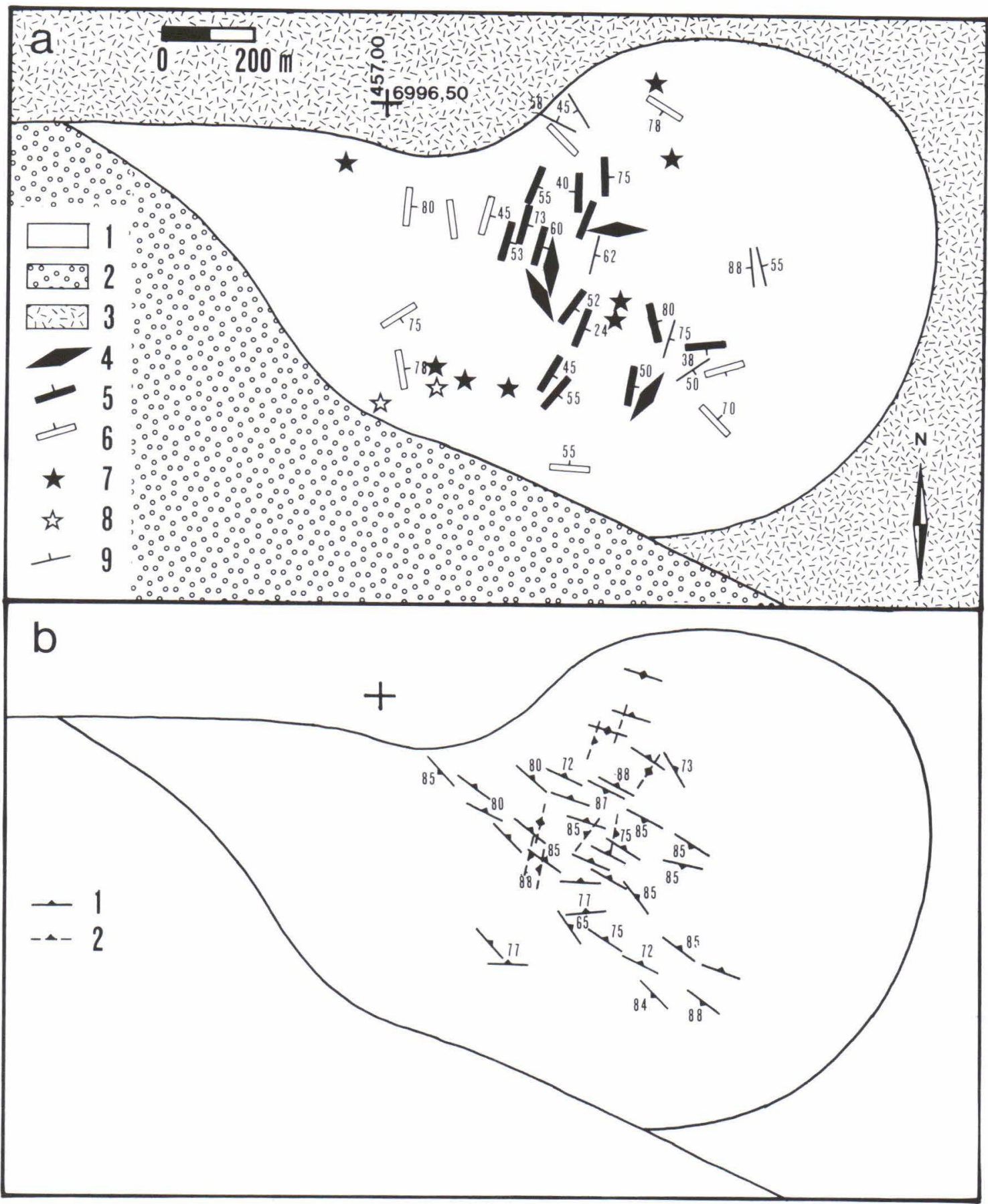

Fig. 4. Rock types and structures in the Mo mineralization at Lahnanen. Reproduced from Nurmi et al. (1984). a) $1=$ hypersthene granite; 2 = coarse-porphyritic granodiorite; 3 = monzogranite; 4 = mineralized pocket of garnet orthoclasite; 5 mineralized garnet orthoclasite vein; $6=$ nonmineralized garnet orthoclasite vein; $7=$ showing of mineralized garnet orthoclasite; $8=$ showing of nonmineralized garnet-ortholclasite; $9=$ mineralized quartz vein. b) $1=\mathrm{S}_{\mathrm{b}} \mathrm{schistosi-}$ ty; 2 axial trace of $S_{c}$ crenulation. 
one deformational episode in the supracrustal rocks preceded $\mathrm{D}_{\mathrm{a}}$ : the diopside-hornblende gneiss xenoliths in the quartz diorite contain a differentiated foliation which is crosscut by the quartz diorite. Penetrative $S_{a}$ foliation can be seen in the marginal type of hypersthene granite at Hirvivuori (Fig. 3). At Hirvivuori, $\mathrm{S}_{\mathrm{a}}$ is crosscut at the contact with the monzogranite, indicating that the latter was emplaced after $\mathrm{D}_{\mathrm{a}}$ deformation. $\mathrm{S}_{\mathrm{a}}$ can rarely be discerned in the quartz diorite because the foliation in the rock is usually a composite one $\left(\mathrm{S}_{\mathrm{a}}-\mathrm{S}_{\mathrm{b}}\right)$.

The prevailing, NW-WNW striking $S_{b}$ foliation is penetrative, or spaced where an older foliation is well developed. In the migmatitic diopside-hornblende gneisses, a few open to tight $F_{b}$ folds were recognized. They are similar in style, with both dextral and sinistral asymmetry, and fold axes plunge gently NW or SE. In the diopside amphibolite at the northern contact of the Mäntylä complex, the penetrative gneissic foliation is folded by $F_{b}$, and a weak $S_{b}$ schistosity, expressed by biotite flakes, can be seen in the axial plane. $\mathrm{S}_{\mathrm{b}}$ can be seen in all granitoids of the complex. In the marginal type of hypersthene granite at Hirvivuori, $\mathrm{S}_{\mathrm{b}}$ crenulates $\mathrm{S}_{\mathrm{a}}$ and is expressed as a set of dextral shear zones $0.5-2 \mathrm{~cm}$ in width (Fig. 3). Deformation partitioning during $D_{b}$ can be seen as intensely foliated zones in the hypersthene granite. In these zones quartz is recrystallized into fine groundmass.

The monzogranite is non-foliated or weakly foliated in the central part. Foliation intensity increases slightly toward the southern and northeastern marginal areas. Here, the foliation can be seen as a preferred orientation of biotite laths, but the large quartz grains show only slight undulose extinction. The foliation may be partly related to external strain $\left(D_{b}\right)$, and partly to emplacement of the monzogranite.

Steeply dipping $S_{c}$ spaced foliation occurs in narrow zones striking NNE. In the hypersthene granite at Lahnanen, $S_{c}$ crenulates $S_{b}$ in a zone about $400 \mathrm{~m}$ wide (Fig. 4). This zone includes the mineralized garnet orthoclasite veins which are subparallel to $S_{c}$. Evidently $D_{c}$ deformation controlled the emplacement of the garnet orthoclasite veins. The pockets do not have a preferred orientation; they may be somewhat older than the veins.

Narrow shear zones overprint $S_{c}$ foliation at Lahnanen, and similar shear zones were observed also in the other hypersthene granite bodies. Shear sense and orientation systematics (dextral $\mathrm{N}-\mathrm{S}$ trending, sinistral E-W trending) was found at Lahnanen but not in the other bodies. The youngest $D_{d}$ structures are shear zones from less than a meter up to several meters in width. The rocks are highly strained and often blastomylonitic in these zones. The trends and dip angles vary considerably (Fig. 2). Chloritic alteration is common.

\section{Geochemistry}

The sample sites for geochemical analyses and symbols of intrusive bodies are shown in Fig. 5. The hypersthene granites do not differ markedly from each other in their major element compositions (Table 1). The mineralized granites (GR1, GR2 and GR4) are somewhat lower in $\mathrm{K}_{2} \mathrm{O}$ than the ones with no observed mineralization (GR5 and GR6). The biotite granite (GR7) is higher in $\mathrm{SiO}_{2}$ and lower in $\mathrm{TiO}_{2}, \mathrm{FeO}$ and $\mathrm{MgO}$ than the hypersthene granites; the major element compositions are generally between those of the hypersthene granites and the monzogranite (GR8). In minor elements, the economically most interesting granite at Lahnanen (GR1) is lower in $\mathrm{Rb}$, Th and $\mathrm{U}$ than the other hypersthene granite bodies (see also Nurmi 1985). The Rb, Th and $\mathrm{U}$ contents in the garnet orthoclasite (GAROR) are considerably higher than in the host hypersthene granite (GR1), e.g. the median value of $\mathrm{Rb}(211 \mathrm{ppm})$ is four times that of $\mathrm{Rb}$ in the granite $(52 \mathrm{ppm})$.

The marginal type of the granitoid at Hirvivuori (GR3) is somewhat lower in $\mathrm{TiO}_{2}$, $\mathrm{Al}_{2} \mathrm{O}_{3}, \mathrm{FeO}, \mathrm{MgO}$ and $\mathrm{CaO}$, and higher in $\mathrm{K}_{2} \mathrm{O}$ 
Table 1. Major and minor element compositions of rocks of the Mäntylä intrusive complex. $\mathrm{N}=\mathrm{Number}$ of analyses; $\operatorname{med}=$ median value; $\min =$ minimum value; $\max =$ maximum value. See text for rock type abbreviations.

\begin{tabular}{|c|c|c|c|c|c|c|c|c|c|}
\hline & \multicolumn{3}{|c|}{$\begin{array}{c}\text { GR1 } \\
(\mathrm{N}=15)\end{array}$} & \multicolumn{3}{|c|}{$\begin{array}{c}\text { GR2 } \\
(\mathrm{N}=20)\end{array}$} & \multicolumn{3}{|c|}{$\begin{array}{c}\text { GR3 } \\
(\mathrm{N}=8)\end{array}$} \\
\hline & med & $\min$ & $\max$ & med & $\min$ & $\max$ & med & $\min$ & $\max$ \\
\hline $\mathrm{SiO} 2(\%)$ & 72.5 & 70.4 & 73.6 & 72.6 & 69.9 & 74.8 & 72.7 & 70.9 & 74.4 \\
\hline $\mathrm{TiO} 2$ & 0.22 & 0.21 & 0.26 & 0.22 & 0.20 & 0.26 & 0.18 & 0.14 & 0.28 \\
\hline $\mathrm{Al} 2 \mathrm{O} 3$ & 14.3 & 13.9 & 14.8 & 14.4 & 13.6 & 15.5 & 13.4 & 12.9 & 14.5 \\
\hline $\mathrm{FeO} *$ & 2.87 & 2.74 & 3.55 & 2.87 & 2.44 & 3.34 & 2.36 & 1.71 & 3.11 \\
\hline $\mathrm{MnO}$ & 0.04 & 0.04 & 0.07 & 0.05 & 0.03 & 0.07 & 0.04 & 0.02 & 0.06 \\
\hline $\mathrm{MgO}$ & 0.44 & 0.37 & 0.47 & 0.45 & 0.36 & 0.58 & 0.35 & 0.31 & 0.51 \\
\hline $\mathrm{CaO}$ & 2.45 & 2.31 & 2.64 & 2.41 & 2.16 & 3.10 & 1.76 & 1.48 & 2.70 \\
\hline $\mathrm{Na} 2 \mathrm{O}$ & 3.70 & 3.57 & 3.95 & 3.75 & 3.23 & 4.16 & 3.49 & 3.11 & 3.76 \\
\hline $\mathrm{K} 2 \mathrm{O}$ & 2.84 & 2.61 & 3.02 & 2.91 & 1.63 & 3.65 & 3.29 & 2.89 & 3.84 \\
\hline $\mathrm{P} 2 \mathrm{O} 5$ & 0.07 & 0.06 & 0.09 & 0.08 & 0.05 & 0.10 & 0.05 & 0.04 & 0.08 \\
\hline $\mathrm{Ba}(\mathrm{ppm})$ & 927 & 105 & 1120 & 855 & 364 & 1110 & 944 & 719 & 1020 \\
\hline $\mathrm{Rb}$ & 52 & 43 & 98 & 73 & 32 & 91 & 82 & 59 & 104 \\
\hline Th & 1.0 & 0.6 & 7.0 & 3.8 & 1.1 & 19.3 & 5.0 & 1.2 & 12.4 \\
\hline $\mathrm{U}$ & 0.5 & 0.4 & 1.2 & 0.9 & 0.5 & 4.9 & 0.6 & 0.4 & 1.6 \\
\hline $\mathrm{K} 2 \mathrm{O} / \mathrm{Na} 2 \mathrm{O}$ & 0.8 & 0.7 & 0.9 & 0.8 & 0.5 & 1.1 & 1.0 & 0.8 & 1.2 \\
\hline
\end{tabular}

\begin{tabular}{|c|c|c|c|c|c|c|c|c|c|c|c|}
\hline & \multicolumn{3}{|c|}{$\begin{array}{c}\text { GR4 } \\
(\mathrm{N}=4)\end{array}$} & \multicolumn{3}{|c|}{$\begin{array}{c}\text { GR5 } \\
(\mathrm{N}=5)\end{array}$} & \multicolumn{2}{|c|}{$\begin{array}{c}\text { GR6 } \\
(\mathrm{N}=2)\end{array}$} & \multicolumn{3}{|c|}{$\begin{array}{c}\text { GR7 } \\
(\mathrm{N}=12)\end{array}$} \\
\hline & med & $\min$ & $\max$ & med & $\min$ & $\max$ & $\min$ & $\max$ & med & $\min$ & $\max$ \\
\hline $\mathrm{SiO}_{2}(\%)$ & 72.9 & 71.7 & 73.5 & 71.8 & 70.4 & 72.4 & 70.2 & 71.7 & 73.5 & 72.8 & 75.8 \\
\hline $\mathrm{TiO} 2$ & 0.22 & 0.21 & 0.27 & 0.23 & 0.16 & 0.23 & 0.23 & 0.30 & 0.16 & 0.12 & 0.18 \\
\hline $\mathrm{A} 12 \mathrm{O} 3$ & 14.3 & 14.1 & 14.7 & 14.4 & 13.2 & 14.8 & 13.9 & 14.3 & 13.0 & 11.7 & 13.2 \\
\hline $\mathrm{FeO}^{*}$ & 2.87 & 2.43 & 3.31 & 2.35 & 1.98 & 2.89 & 2.44 & 2.82 & 1.96 & 1.65 & 2.42 \\
\hline $\mathrm{MnO}$ & 0.05 & 0.04 & 0.05 & 0.05 & 0.04 & 0.06 & 0.05 & 0.06 & 0.02 & 0.02 & 0.03 \\
\hline $\mathrm{MgO}$ & 0.46 & 0.39 & 0.48 & 0.45 & 0.28 & 0.49 & 0.48 & 0.70 & 0.29 & 0.21 & 0.35 \\
\hline $\mathrm{CaO}$ & 2.30 & 2.25 & 2.50 & 2.40 & 1.65 & 2.75 & 2.13 & 2.35 & 1.58 & 0.82 & 1.73 \\
\hline $\mathrm{Na} 2 \mathrm{O}$ & 3.58 & 3.42 & 3.71 & 3.50 & 2.98 & 3.67 & 3.48 & 3.53 & 3.30 & 2.48 & 3.54 \\
\hline $\mathrm{K} 2 \mathrm{O}$ & 3.04 & 2.89 & 3.08 & 3.25 & 2.99 & 3.52 & 3.37 & 3.47 & 3.43 & 3.25 & 4.67 \\
\hline $\mathrm{P} 2 \mathrm{O} 5$ & 0.08 & 0.07 & 0.09 & 0.08 & 0.04 & 0.09 & 0.01 & 0.08 & 0.03 & 0.02 & 0.04 \\
\hline $\mathrm{Ba}(\mathrm{ppm})$ & 875 & 857 & 993 & 1100 & 947 & 1190 & 773 & 814 & 1085 & 979 & 1320 \\
\hline $\mathrm{Rb}$ & 74 & 59 & 81 & 74 & 57 & 91 & 89 & 112 & 102 & 73 & 121 \\
\hline Th & 5.8 & 2.8 & 7.6 & 5.3 & 1.5 & 7.4 & 1.0 & 2.2 & 6.3 & 2.2 & 11.0 \\
\hline $\mathrm{U}$ & 0.9 & 0.7 & 1.7 & 0.9 & 0.8 & 1.5 & 0.9 & 1.5 & 0.8 & 0.6 & 1.8 \\
\hline $\mathrm{K} 2 \mathrm{O} / \mathrm{Na} 2 \mathrm{O}$ & 0.8 & 0.8 & 0.9 & 0.9 & 0.8 & 1.2 & 1.0 & 1.0 & 1.0 & 1.0 & 1.9 \\
\hline
\end{tabular}

* Total $\mathrm{Fe}$ as $\mathrm{FeO}$ 
(Continued)

\begin{tabular}{|c|c|c|c|c|c|c|c|c|c|}
\hline & & $\begin{array}{c}\text { GR8 } \\
(\mathrm{N}=27)\end{array}$ & & & $\begin{array}{l}\text { GRDR } \\
\mathrm{N}=14)\end{array}$ & & & $\begin{array}{c}\text { QDR } \\
(\mathrm{N}=14)\end{array}$ & \\
\hline & med & $\min$ & $\max$ & med & $\min$ & $\max$ & med & $\min$ & $\max$ \\
\hline $\mathrm{SiO} 2(\%)$ & 74.8 & 72.5 & 76.9 & 68.4 & 58.2 & 72.4 & 63.7 & 55.4 & 67.9 \\
\hline $\mathrm{TiO} 2$ & 0.14 & 0.09 & 0.22 & 0.38 & 0.17 & 1.13 & 0.63 & 0.41 & 1.22 \\
\hline $\mathrm{Al} 2 \mathrm{O} 3$ & 13.0 & 12.5 & 14.7 & 15.9 & 12.9 & 17.6 & 16.2 & 15.0 & 19.7 \\
\hline $\mathrm{FeO}^{*}$ & 1.84 & 1.43 & 2.76 & 3.52 & 2.02 & 9.05 & 5.99 & 4.82 & 10.8 \\
\hline $\mathrm{MnO}$ & 0.04 & 0.02 & 0.04 & 0.06 & 0.03 & 0.15 & 0.12 & 0.08 & 0.19 \\
\hline $\mathrm{MgO}$ & 0.31 & 0.18 & 0.51 & 1.22 & 0.31 & 4.57 & 1.30 & 0.65 & 2.39 \\
\hline $\mathrm{CaO}$ & 1.34 & 0.90 & 2.44 & 1.80 & 1.46 & 4.65 & 4.49 & 2.88 & 7.18 \\
\hline $\mathrm{Na} 2 \mathrm{O}$ & 3.36 & 3.14 & 3.67 & 2.95 & 2.58 & 4.03 & 3.56 & 3.18 & 5.49 \\
\hline $\mathrm{K} 2 \mathrm{O}$ & 3.62 & 3.15 & 4.48 & 4.28 & 2.36 & 5.45 & 1.49 & 0.78 & 3.25 \\
\hline $\mathrm{P} 2 \mathrm{O} 5$ & 0.04 & 0.02 & 0.08 & 0.23 & 0.04 & 0.47 & 0.20 & 0.12 & 0.52 \\
\hline $\mathrm{Ba}(\mathrm{ppm})$ & 1030 & 708 & 1540 & 939 & 531 & 1370 & 652 & 246 & 1080 \\
\hline $\mathrm{Rb}$ & 91 & 49 & 116 & 151 & 54 & 237 & 38 & 16 & 158 \\
\hline Th & 9.5 & 4.6 & 16.1 & 11.0 & 3.1 & 22.3 & 1.4 & 0.4 & 4.7 \\
\hline $\mathrm{U}$ & 1.6 & 0.5 & 3.1 & 2.5 & 0.7 & 4.1 & 0.8 & 0.3 & 1.8 \\
\hline $\mathrm{K} 2 \mathrm{O} / \mathrm{Na} 2 \mathrm{O}$ & 1.1 & 0.9 & 1.4 & 1.4 & 0.7 & 2.0 & 0.4 & 0.2 & 1.0 \\
\hline & & $\begin{array}{c}\mathrm{DR} \\
(\mathrm{N}=5)\end{array}$ & & & $\begin{array}{c}\text { GB } \\
(\mathrm{N}=5)\end{array}$ & & & $\begin{array}{r}\text { GARO } \\
(\mathrm{N}=7\end{array}$ & \\
\hline
\end{tabular}

\begin{tabular}{|c|c|c|c|c|c|c|c|c|c|}
\hline & med & $\min$ & $\max$ & med & $\min$ & $\max$ & med & $\min$ & $\max$ \\
\hline $\mathrm{SiO}_{2}(\%)$ & 58.8 & 49.1 & 62.1 & 48.0 & 44.2 & 51.7 & 58.0 & 56.7 & 59.9 \\
\hline $\mathrm{TiO} 2$ & 0.89 & 0.79 & 1.15 & 1.03 & 0.65 & 1.59 & 0.28 & 0.03 & 0.43 \\
\hline $\mathrm{Al} 2 \mathrm{O} 3$ & 17.1 & 16.6 & 19.0 & 17.5 & 8.7 & 21.4 & 17.4 & 16.5 & 18.0 \\
\hline $\mathrm{FeO} *$ & 6.74 & 6.22 & 9.66 & 9.67 & 8.65 & 11.8 & 12.3 & 9.48 & 13.3 \\
\hline $\mathrm{MnO}$ & 0.12 & 0.11 & 0.15 & 0.16 & 0.14 & 0.19 & 0.20 & 0.14 & 0.24 \\
\hline $\mathrm{MgO}$ & 3.59 & 2.90 & 5.47 & 7.68 & 4.13 & 15.5 & 0.59 & 0.46 & 0.84 \\
\hline $\mathrm{CaO}$ & 5.73 & 5.66 & 8.90 & 9.99 & 7.18 & 12.1 & 1.11 & 0.71 & 1.78 \\
\hline $\mathrm{Na} 2 \mathrm{O}$ & 3.31 & 3.12 & 3.48 & 2.56 & 1.16 & 3.12 & 3.52 & 2.76 & 3.71 \\
\hline $\mathrm{K} 2 \mathrm{O}$ & 2.40 & 1.54 & 2.59 & 0.94 & 0.68 & 1.60 & 6.10 & 4.73 & 7.97 \\
\hline $\mathrm{P} 2 \mathrm{O} 5$ & 0.28 & 0.26 & 0.42 & 0.15 & 0.10 & 1.03 & 0.10 & 0.07 & 0.13 \\
\hline $\mathrm{Ba}(\mathrm{ppm})$ & 768 & 492 & 859 & 408 & 179 & 740 & 1140 & 685 & 1400 \\
\hline $\mathrm{Rb}$ & 61 & 46 & 75 & 29 & 18 & 60 & 211 & 172 & 352 \\
\hline Th & 1.9 & 1.0 & 4.4 & 0.8 & 0.4 & 1.0 & 2.9 & 1.7 & 8.1 \\
\hline $\mathrm{U}$ & 0.9 & 0.8 & 1.4 & 0.6 & 0.3 & 0.8 & 1.1 & 0.7 & 2.8 \\
\hline $\mathrm{K} 2 \mathrm{O} / \mathrm{Na} 2 \mathrm{O}$ & 0.7 & 0.5 & 0.7 & 0.6 & 0.3 & 0.7 & 1.8 & 1.3 & 2.9 \\
\hline
\end{tabular}

The major and minor elements (upper part) were analysed by XRF at the Rautaruukki Oy Research Laboratories. $\mathrm{Ba}, \mathrm{Rb}$, Th and $\mathrm{U}$ were determined by internal neutron activation at the Reactor Laboratory of the Technical Research Centre of Finland. Complete analytical data is available on request to the authors. 


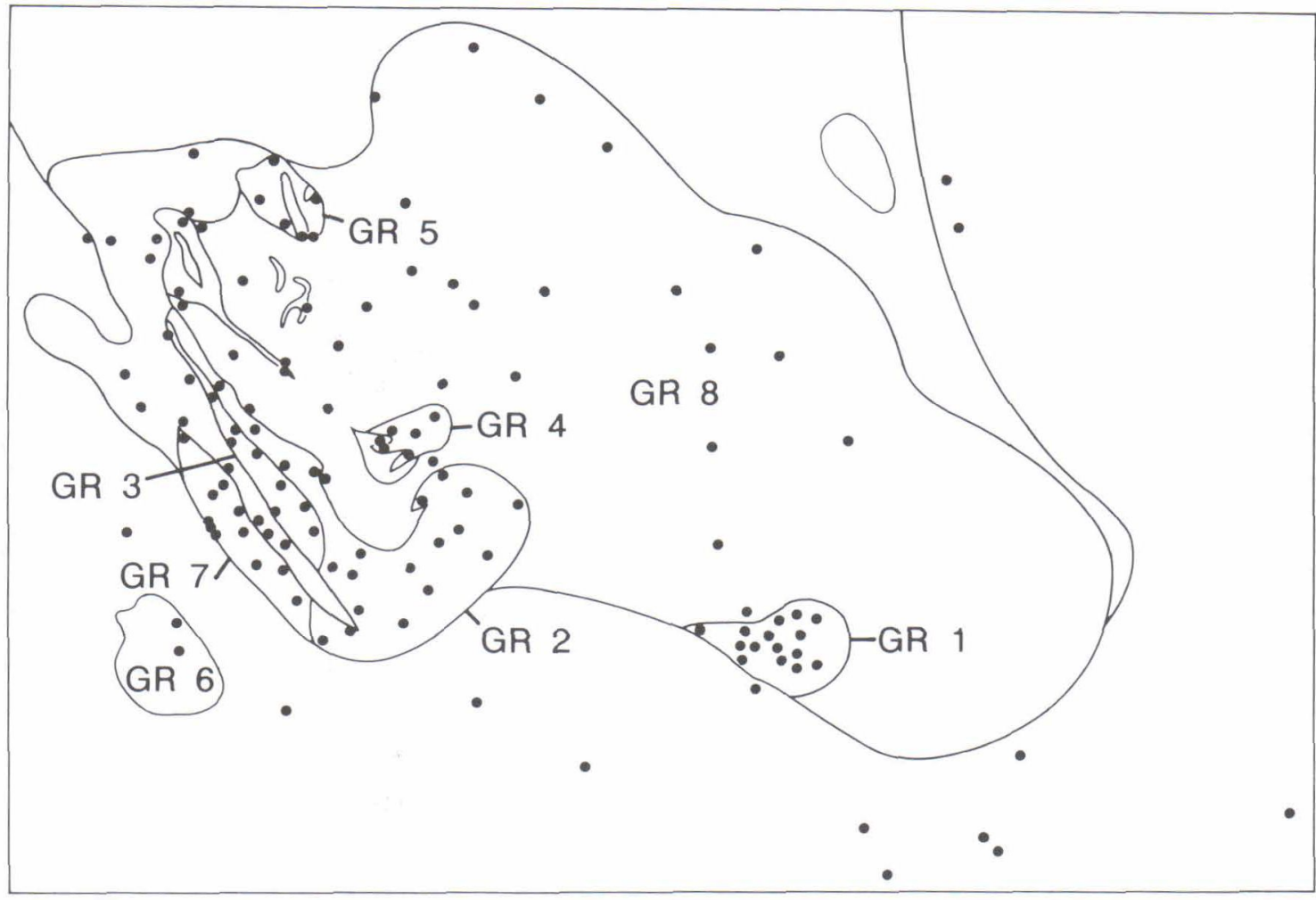

Fig. 5. Sample sites in the Mäntylä complex. GR $1-6=$ hypersthene granite; GR $7=$ biotite granite; GR $8=$ monzogranite.

than the rest of the body (GR2). The change in composition cannot be due to contamination by the migmatitic hornblende gneiss. More probably the reason for change is an influx of hydrothermal fluids which caused silicification, $\mathrm{K}$-feldspathization, and $\mathrm{Cu}$-As mineralization.

In the $\mathrm{K}_{2} \mathrm{O}$ versus $\mathrm{SiO}_{2}$ diagram, the hypersthene granites plot as a fairly coherent group (Fig. 6a). The hypersthene granites, the biotite granite (GR7) and the monzogranite (GR8) constitute a positive trend. The biotite granite is geochemically closer to the monzogranite although it petrographically and by the naked eye resembles the hypersthene granites. This can be seen in the $\mathrm{Rb}$ versus $\mathrm{TiO}_{2}$ diagram (Fig. 6b). The three rock groups may have evolved from a common magma, and the biotite granite apparently represents a transitional type between the two other magma pulses.

The coarse-porphyritic granitoids (GRDR) plot as two groups (Fig. 6). The felsic group, granitic in composition, differs from the other granitoids in being richer in the mobile elements $\mathrm{K}_{2} \mathrm{O}$ and $\mathrm{Rb}$ as well as in Th and U. The garnet orthoclasite shows a similar yet stronger enrichment of these elements.

The quartz diorite (QDR) and the more mafic rocks are geochemically heterogeneous. Contamination by the supracrustal rocks is probably the reason for the diversity in the composition of the quartz diorite. The monzodiorite (DR) is higher in $\mathrm{K}_{2} \mathrm{O}$ than the quartz diorite at the same $\mathrm{SiO}_{2}$ range (Fig. 6a); apparently these rock types are not comagmatic. The geochemical heterogeneity of the metagabbros (GB) can also be seen at outcrops e.g. as compositional banding. 

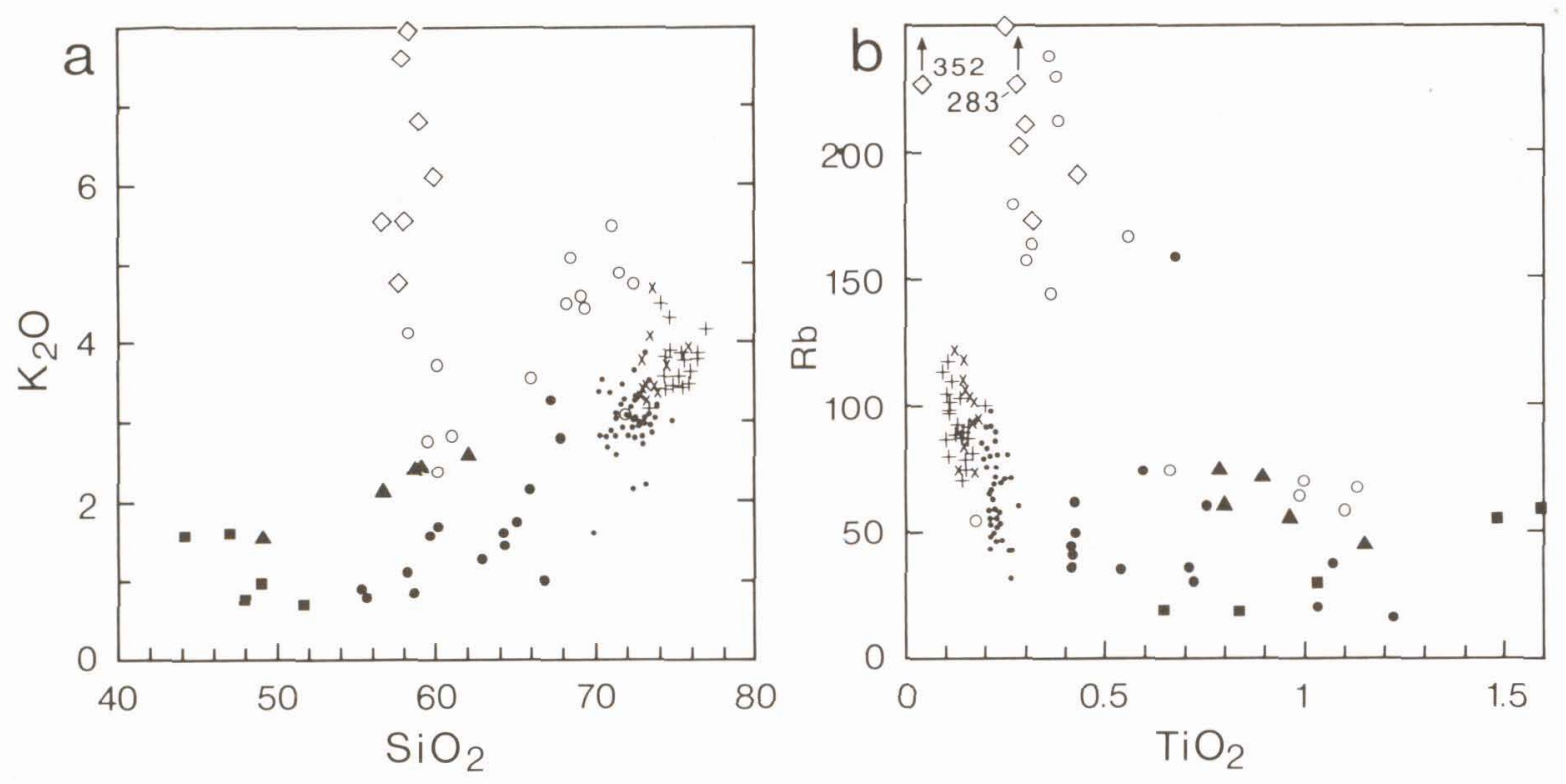

$\begin{array}{llll}\cdot \mathrm{GR} 1-6 & +\mathrm{GR} 8 & \bullet \mathrm{QDR} & =\mathrm{GB} \\ \times \mathrm{GR} 7 & \circ \mathrm{GRDR} & \triangle \mathrm{DR} & \diamond \mathrm{GAROR}\end{array}$

Fig. 6. Geochemical diagrams of the rocks in the Mäntylä complex. a) $\mathrm{K}_{2} \mathrm{O}$ vs. $\mathrm{SiO}_{2}$, b) $\mathrm{Rb}$ vs. $\mathrm{TiO}_{2}$. $\mathrm{Rb}$ as ppm, others as $\%$. GR $1-6=$ hypersthene granite, GR $7=$ biotite granite, GR $8=$ monzogranite, GRDR = coarse-porphyritic granitoid, $\mathrm{QDR}=$ quartz diorite, $\mathrm{DR}=$ monzodiorite, $\mathrm{GB}=$ metagabbro, GAROR = garnet orthoclasite.

\section{Emplacement of the plutonic rocks}

The metagabbros were emplaced before $\mathrm{D}_{\mathrm{a}}$ deformation, but their emplacement with respect to the early foliation visible in the supracrustal rocks is unclear. The monzodiorite intruded contemporarily or somewhat earlier than the quartz diorite, but the geochemical diagrams suggest that the two magmas came from separate sources. The quartz diorite intruded before or during an early $D_{a}$ stage, and migmatized the previously metamorphosed hornblende gneisses. Subsequent emplacement of the Hirvivuori hypersthene granodiorite, during $\mathrm{D}_{\mathrm{a}}$, caused a contact metamorphic zone into the migmatitic rock.

The hypersthene granite at Hirvivuori intruded earlier than the other hypersthene granite bod- ies. Because the hypersthene granites are petrographically and geochemically similar, they probably had a common source. The biotite granite as well as the monzogranite possibly ascended from the same source as the hypersthene granites, but later during $\mathrm{D}_{\mathrm{b}}$ deformation. The weak foliation visible in the monzogranite suggests intrusion at a late stage of $\mathrm{D}_{\mathrm{b}}$. The increase of foliation intensity toward the northeastern and southern contacts suggests forceful (diapiric?) emplacement for the monzogranite.

Contact relationships indicate that the coarseporphyritic granitoids intruded after the hypersthene granites. Considering the geochemical heterogeneity, the coarse-porphyritic granitoids apparently intruded as several pulses during $D_{b}$ deformation.

By the time of $\mathrm{D}_{\mathrm{c}}$ deformation the plutonic 
Table 2. U-Pb isotopic data from the Mäntylä intrusive complex.

\begin{tabular}{|c|c|c|c|c|c|c|c|c|c|c|}
\hline \multirow[t]{2}{*}{ Sample } & \multirow[t]{2}{*}{$\begin{array}{l}\text { Fraction } \\
\left(\mathrm{g} / \mathrm{cm}^{3}\right)\end{array}$} & \multicolumn{2}{|c|}{$\begin{array}{c}\text { Concentration } \\
(\mu \mathrm{g} / \mathrm{g})\end{array}$} & \multirow[t]{2}{*}{$\begin{array}{c}\text { Measured } \\
{ }^{206} \mathrm{~Pb} /{ }^{204} \mathrm{~Pb}\end{array}$} & \multicolumn{3}{|c|}{$\begin{array}{l}\text { Isotopic composition of lead } \\
\qquad\left({ }^{206} \mathrm{~Pb}=100\right)\end{array}$} & \multicolumn{3}{|c|}{ Atom ratios and radiometric ages, $\mathrm{Ma}$} \\
\hline & & $238 \mathrm{U}$ & $206 \mathrm{~Pb}$ & & ${ }^{204} \mathrm{~Pb}$ & ${ }^{207} \mathrm{~Pb}$ & ${ }^{208} \mathrm{~Pb}$ & $206 \mathrm{~Pb} / 238 \mathrm{U}$ & ${ }^{207} \mathrm{~Pb} / 235_{\mathrm{U}}$ & ${ }^{207} \mathrm{~Pb} / 206 \mathrm{~Pb}$ \\
\hline \multirow[t]{6}{*}{ A160 quartz diorite } & A d $>4.6$ & 474.1 & 136.05 & 12692 & 0.007244 & 11.605 & 7.455 & 0.3317 & 5.263 & 0.11508 \\
\hline & & & & & & & & 1846 & 1862 & $1881 \pm 7$ \\
\hline & B $4.2<d<4.6$ & 649.2 & 180.56 & 11917 & 0.007897 & 11.579 & 7.447 & 0.3214 & 5.084 & 0.11472 \\
\hline & & & & & & & & 1796 & 1833 & $1875 \pm 6$ \\
\hline & C $4.0<\mathrm{d}<4.2$ & 869.3 & 236.48 & 6693 & 0.01447 & 11.638 & 7.487 & 0.3144 & 4.960 & 0.11442 \\
\hline & & & & & & & & 1762 & 1812 & $1870 \pm 5$ \\
\hline \multirow{6}{*}{$\begin{array}{l}\text { A161 gabbro } \\
\text { pegmatoid }\end{array}$} & $\mathrm{Ad}>4.6 ; \mathrm{O}>160$ & 532.9 & 153.94 & 82146 & 0.0005717 & 11.512 & 8.081 & 0.3339 & 5.296 & 0.11504 \\
\hline & HF & & & & & & & 1857 & 1868 & $1880 \pm 5$ \\
\hline & $\mathrm{Bd}>4.6 ; \mathrm{O}>160$ & 594.3 & 168.86 & 13366 & 0.006949 & 11.574 & 8.280 & 0.3284 & 5.198 & 0.11480 \\
\hline & & & & & & & & 1830 & 1852 & $1876 \pm 9$ \\
\hline & $C 4.0<d<4.2$ & 1315 & 360.12 & 11471 & 0.008376 & 11.565 & 6.369 & 0.3166 & 4.999 & 0.11452 \\
\hline & $\mathrm{O}>160$ & & & & & & & 1773 & 1819 & $1872 \pm 5$ \\
\hline \multirow{8}{*}{$\begin{array}{l}\text { A392 hypersthene } \\
\text { granite }\end{array}$} & A $4.2<$ d $<4.6$ & 695.8 & 198.78 & 28268 & 0.002220 & 11.551 & 7.314 & 0.3302 & 5.245 & 0.11521 \\
\hline & & & & & & & & 1839 & 1859 & $1883 \pm 13$ \\
\hline & B monazite & 1923 & 555.73 & 34541 & 0.001774 & 11.454 & 549.01 & 0.3340 & 5.264 & 0.11430 \\
\hline & abr & & & & & & & 1857 & 1863 & $1869 \pm 5$ \\
\hline & C $4.0<\mathrm{d}<4.2$ & 1076 & 294.44 & 8259 & 0.01085 & 11.604 & 8.097 & 0.3163 & 4.996 & 0.11457 \\
\hline & $a b r$ & & & & & & & 1771 & 1818 & $1873 \pm 4$ \\
\hline & D $4.2<d<4.6$ & 721.5 & 208.15 & 14317 & 0.006217 & 11.594 & 7.416 & 0.3335 & 5.292 & 0.11510 \\
\hline & $a b r$ & & & & & & & 1855 & 1867 & $1881 \pm 5$ \\
\hline \multirow{3}{*}{$\begin{array}{l}80-02154 \text { monzo- } \\
\text { granite }\end{array}$} & A d $>3.8$ & 1073 & 262.41 & 5163 & 0.01597 & 11.657 & 10.000 & 0.2826 & 4.458 & 0.11441 \\
\hline & $\begin{array}{c}\text { abr } \\
\text { B monazite }\end{array}$ & 1914 & 55571 & 5435 & 0.01626 & 11746 & 616.04 & $\begin{array}{c}1604 \\
0.3355\end{array}$ & $\begin{array}{r}1723 \\
5.332\end{array}$ & $\begin{array}{c}1870 \pm 11 \\
0.11527\end{array}$ \\
\hline & abr & 1914 & (30J. & $34 J 5$ & 0.01020 & 11.140 & 010.04 & $\begin{array}{l}1865 \\
1865\end{array}$ & $\begin{array}{l}3.332 \\
1874\end{array}$ & $1884 \pm 9$ \\
\hline \multirow{5}{*}{$\begin{array}{l}\text { A391 orbicular } \\
\text { quartz diorite }(* 1)\end{array}$} & $\mathrm{A} \mathrm{O}>70$ & 1614 & 405.08 & 1926 & 0.04483 & 11.957 & 4.327 & 0.2902 & 4.541 & 0.11350 \\
\hline & borax fusion & & & & & & & 1642 & 1738 & $1856 \pm 24$ \\
\hline & B monazite & 2191 & 607.04 & 4998 & - & 11.034 & 388.66 & 0.3203 & 4.872 & 0.11034 \\
\hline & C $4.0<d<4.2$ & 1270 & 364.10 & 3324 & 0.02893 & 11.857 & 4.278 & $\begin{array}{c}1791 \\
0.3314\end{array}$ & $\begin{array}{c}1797 \\
5.238\end{array}$ & $\begin{array}{c}1805 \pm 52 \\
0.11465\end{array}$ \\
\hline & $\mathrm{O}>160 ; \mathrm{abr}$ & & & & & & & 1845 & 1858 & $1874 \pm 9$ \\
\hline
\end{tabular}


Table 2, continued.

\begin{tabular}{|c|c|c|c|c|c|c|c|c|c|c|}
\hline \multirow[t]{2}{*}{ Sample } & \multirow[t]{2}{*}{$\begin{array}{l}\text { Fraction } \\
\left(\mathrm{g} / \mathrm{cm}^{3}\right)\end{array}$} & \multicolumn{2}{|c|}{$\begin{array}{l}\text { Concentration } \\
(\mu \mathrm{g} / \mathrm{g})\end{array}$} & \multirow[t]{2}{*}{$\begin{array}{c}\text { Measured } \\
{ }^{206} \mathrm{~Pb} / 204 \mathrm{~Pb}\end{array}$} & \multicolumn{3}{|c|}{$\begin{array}{l}\text { Isotopic composition of lead } \\
\qquad\left({ }^{206} \mathrm{~Pb}=100\right)\end{array}$} & \multicolumn{3}{|c|}{ Atom ratios and radiometric ages, $\mathrm{Ma}$} \\
\hline & & ${ }^{238} \mathrm{U}$ & $206 \mathrm{~Pb}$ & & ${ }^{204} \mathrm{~Pb}$ & ${ }^{207} \mathrm{~Pb}$ & ${ }^{208} \mathrm{~Pb}$ & ${ }^{206} \mathrm{~Pb} / 238 \mathrm{U}$ & ${ }^{207} \mathrm{~Pb} / 235 \mathrm{U}$ & ${ }^{207} \mathrm{~Pb} /{ }^{206} \mathrm{~Pb}$ \\
\hline \multirow[t]{8}{*}{$\begin{array}{l}\text { A } 290 \text { garnet } \\
\text { orthoclasite }\end{array}$} & $\begin{array}{c}\text { A } 4.2<\mathrm{d}<4.6 \\
\mathrm{O}<70 ; \mathrm{abr}\end{array}$ & 788.1 & 225.05 & 8073 & 0.01089 & 11.658 & 5.369 & $\begin{array}{c}0.3300 \\
1838\end{array}$ & $\begin{array}{c}5.237 \\
1858\end{array}$ & $\begin{array}{l}0.11510 \\
1881+5\end{array}$ \\
\hline & $\mathrm{B} d>4.6$ & 298.1 & 86.91 & 29593 & 0.0008177 & 11.477 & 6.347 & 0.3369 & 5.326 & 0.11466 \\
\hline & abr & & & & & & & 1871 & 1873 & $1874 \pm 11$ \\
\hline & $\begin{array}{l}C 4.2<\mathrm{d}<4.6 ; \\
\quad \text { O }>70 ; \text { abr; dark } \\
\text { short crystals }\end{array}$ & 650.6 & 188.16 & 35448 & 0.001511 & 11.497 & 5.159 & $\begin{array}{c}0.3342 \\
1858\end{array}$ & $\begin{array}{l}5.289 \\
1867\end{array}$ & $\begin{array}{c}0.11477 \\
1876 \pm 10\end{array}$ \\
\hline & $\begin{array}{c}\text { D } 4.2<\mathrm{d}<4.6 \\
\mathrm{O}<70 ; \text { abr }\end{array}$ & 829.3 & 238.31 & 24026 & 0.002720 & 11.534 & 5.167 & $\begin{array}{c}0.3321 \\
1848\end{array}$ & $\begin{array}{c}5.265 \\
1863\end{array}$ & $\begin{array}{l}0.11497 \\
1879 \pm 8\end{array}$ \\
\hline & $\begin{array}{l}\text { E } 4.2<\mathrm{d}<4.6 \\
\quad \mathrm{O}>130 ; \mathrm{abr} \\
\text { turbid }\end{array}$ & 788.4 & 228.49 & 25563 & 0.002567 & 11.540 & 4.991 & $\begin{array}{c}0.3350 \\
1862\end{array}$ & $\begin{array}{c}5.313 \\
1871\end{array}$ & $\begin{array}{l}0.11505 \\
1880 \pm 8\end{array}$ \\
\hline & $\begin{array}{c}\text { F } 4.2<\mathrm{d}<4.6 ; \text { abr } \\
\text { long crystals }\end{array}$ & 776.0 & 226.70 & 16930 & 0.002485 & 11.539 & 5.928 & $\begin{array}{c}0.3376 \\
1875\end{array}$ & $\begin{array}{c}5.356 \\
1877\end{array}$ & $\begin{array}{c}0.11506 \\
1880 \pm 10\end{array}$ \\
\hline & $\begin{array}{l}\text { G } 4.2<\text { d }<4.6 ; \text { abr } \\
\text { dark crystals }\end{array}$ & 657.5 & 192.27 & 29060 & 0.001960 & 11.498 & 5.360 & $\begin{array}{c}0.3380 \\
1876\end{array}$ & $\begin{array}{c}5.346 \\
1876\end{array}$ & $\begin{array}{l}0.11472 \\
1875 \pm 5\end{array}$ \\
\hline
\end{tabular}

All fractions are zircon unless otherwise indicated. $d=$ density; $O=\operatorname{size}(\mu \mathrm{m}) ; \mathrm{HF}=$ preleached in $\mathrm{HF} ; \mathrm{abr}=$ grains abraded.

*1 Recalculated from Aho (1979). 


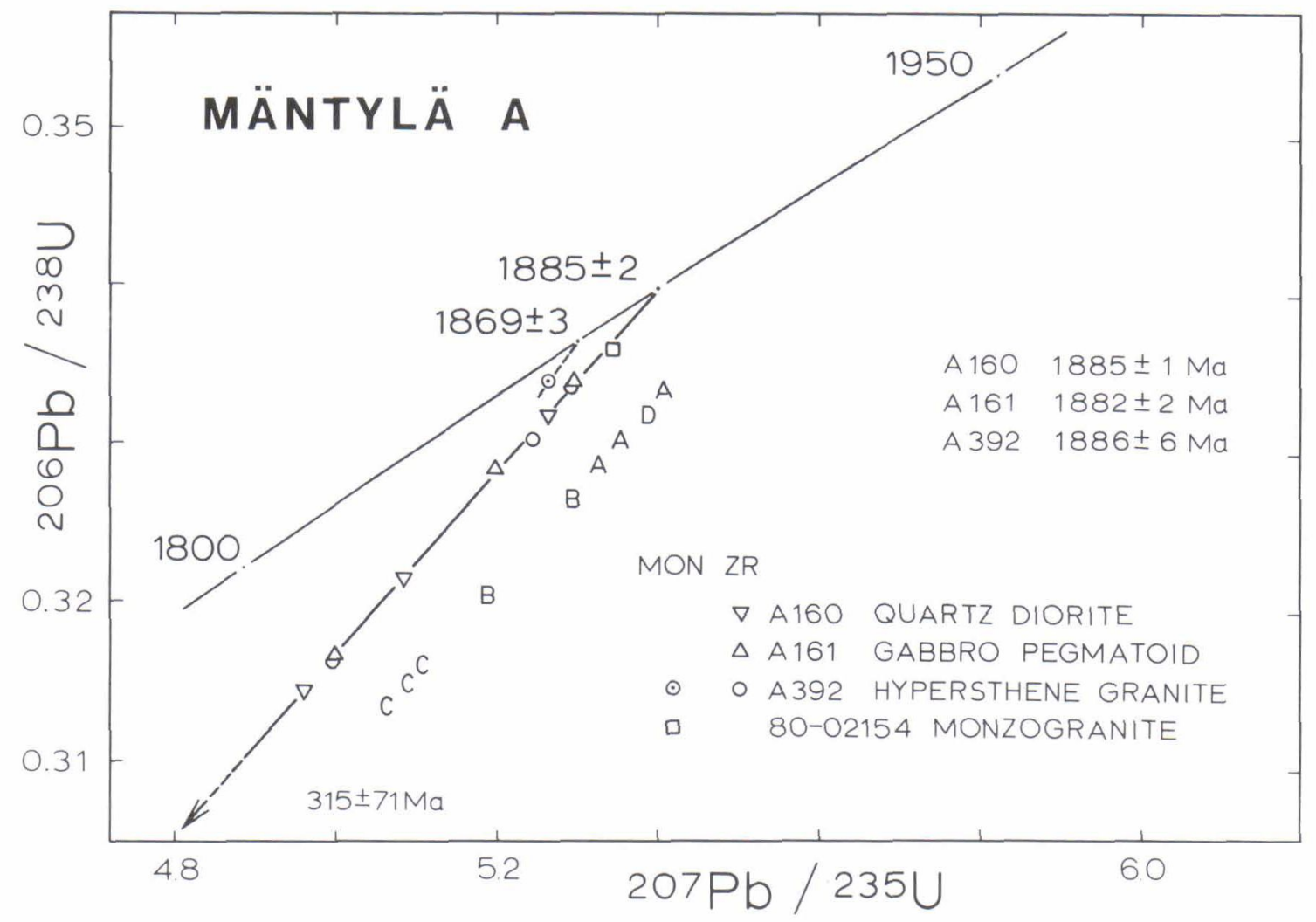

Fig. 7. U-Pb data of the rocks in the Mäntylä complex. a) Concordia diagram on the igneous rocks of the Mäntylä complex. The data of quartz diorite (A 160) and gabbro pegmatoid (A 161) were previously published by Nurmi et al. (1984). b) Concordia diagram on garnet orthoclasite and orbicular quartz diorite.

complex had cooled so much that strain concentrated in narrow zones. During late $\mathrm{D}_{\mathrm{c}}$, strain localized as small shear zones in the hypersthene granites. $D_{c}$ and $D_{d}$ deformation are probably closely associated in time and may even be expressions of a single progressive deformational event.

\section{$\mathrm{U}-\mathrm{Pb}$ isotopic data}

$\mathrm{U}-\mathrm{Pb}$ isotopic zircon analyses were made of six rock types, and monazite analyses were made of three rock types (Table 2, Fig. 7). The analyses of the quartz diorite, the gabbro pegmatoid, and the hypersthene granite yield ages between 1886 Ma and $1882 \mathrm{Ma}$ (Fig. 7a). The pooled age of the three rock types is $1885 \mathrm{Ma}$. The single analysed fraction from the monzogranite (not shown in Fig. 7a) yields a minimum age of $1870 \mathrm{Ma}$, and monazite from the same sample gives $1884 \pm 3$ Ma (Table 2). These results suggest an age around $1880 \mathrm{Ma}$ for the monzogranite. Monazite from the hypersthene granite gives an age of $1869 \mathrm{Ma}$.

The garnet orthoclasite and the orbicular quartz diorite yield a pooled age of $1876 \mathrm{Ma}$ (Fig. 7b). Four fractions of the garnet orthoclasite give an age of $1880 \mathrm{Ma}$. The slightly discordant fractions A, D and F (dashed line in Fig. 7b) suggest an older component in the garnet orthoclasite. Monazite from the orbicular quartz diorite gives a distinctly lower age of $1805 \mathrm{Ma}$ (see also Aho 1979). 


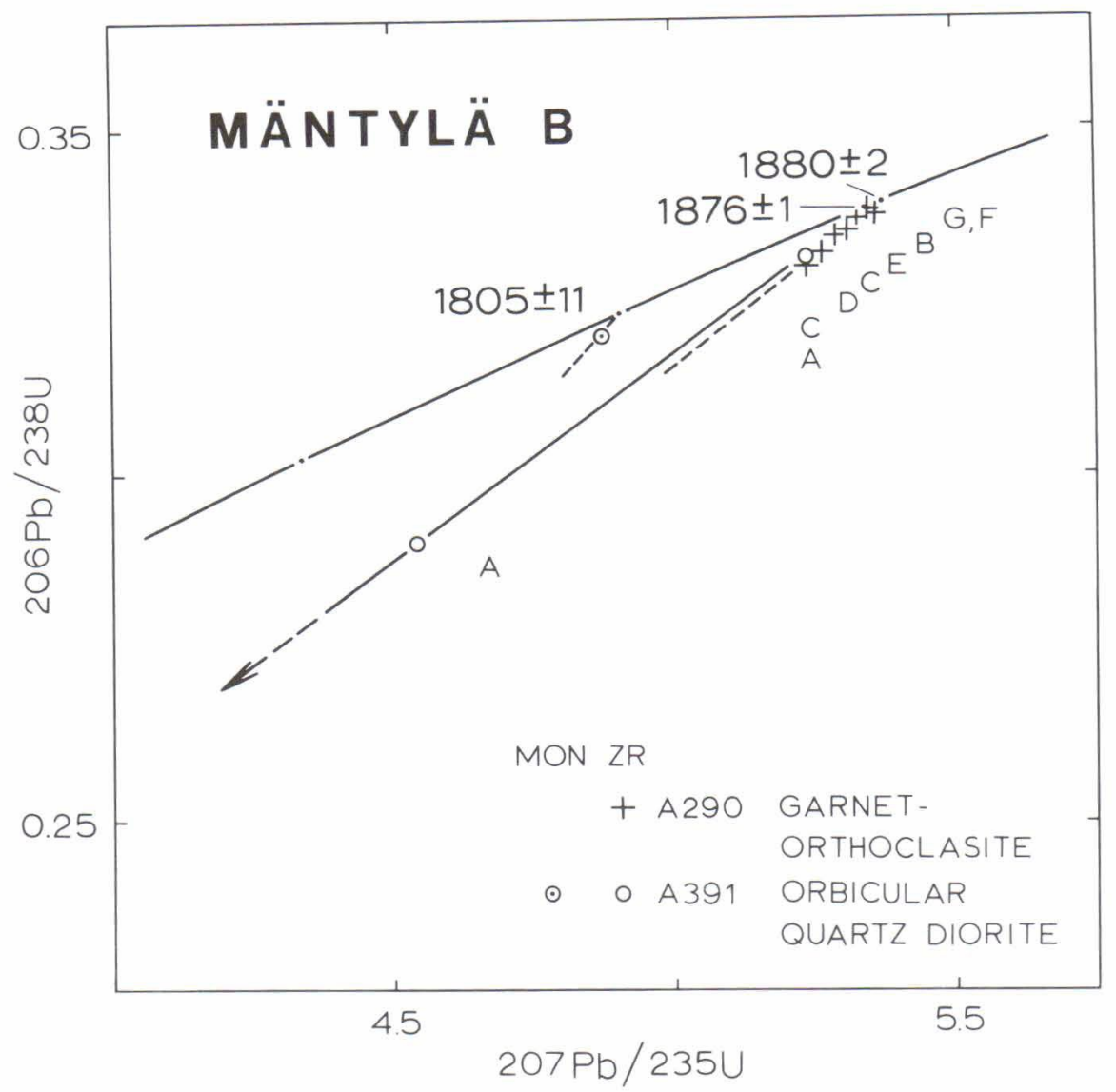

\section{Discussion}

The hypersthene granitoids, the hypersthenebearing coarse-porphyritic granitoids as well as the garnet orthoclasite represent a relatively deep and dry source area in the Svecofennian crust. However, the geochemical characteristics of the rocks show that the magmas were derived from different source materials. Only the felsic members, i.e. the hypersthene granites, the biotite granite and the monzogranite, are possibly comagmatic.

The mafic-felsic emplacement sequence started before $\mathrm{D}_{\mathrm{a}}$ deformation and ended by the end of $\mathrm{D}_{\mathrm{b}}$; this episode occurred $1886-1880 \mathrm{Ma}$ ago. The small time lapse between intrusions is seen as gradating or sharp contacts instead of brecciating ones (except for the older metagabbros). The successive intrusive pulses migmatized and altered the previously metamorphosed supracrustal rocks. The formation of the 1880 Ma old garnet orthoclasite also gives the age of $\mathrm{D}_{\mathrm{c}}$ deformation. This example shows how complex structural-metamorphic overprinting may be generated during a relatively short time interval.

The petrological and geochemical similarity of the hypersthene granite bodies strongly suggests a common source. Possibly the emplacement of the monzogranite pushed apart the originally closely arranged hypersthene granites. Push-apart mechanism would explain the slight mineralogical differences between the bodies and also why 
only some of the bodies are mineralized.

The garnet orthoclasite was previously explained in terms of an alkali-iron-rich remnant liquid of the hypersthene granite magma (Nur$\mathrm{mi}$ et al. 1984). The $\mathrm{Mo}$ and $\mathrm{Cu}$ anomalies in the hypersthene granite at Lahnanen, measured from bedrock and till samples, concentrate in a WNWESE trending zone (Nurmi et al. 1984). This trend is approximately parallel to $S_{b}$ foliation. Nurmi (1985) suggested that the chalcophile trace elements (e.g. Mo and $\mathrm{Cu}$ ) accumulated in the central part of the body , and were later remobilized and enriched by K-rich solutions (fluids). The fluid inclusions in quartz of the garnet orthoclasite as well as in the host hypersthene granite are mostly gaseous-type; the lack of salt-rich inclusions and the scarcity of inclusions in general suggest that the rock was not subjected to strong hydrothermal alteration (K. Kinnunen 1991, personal communication). This is in accordance with

\section{References}

Aho, L., 1979. Petrological and geochemical studies of metavolcanics and associated granitoids in the Pihtipudas area, Central Finland. Geological Survey of Finland, Bulletin 300, 22 p.

Front, K. \& Nurmi, P.A., 1987. Characteristics and geological setting of synkinematic Svecokarelian granitoids in southern Finland. Precambrian Research 35, 207-224.

Huhma, H., 1986. Sm-Nd, U-Pb and $\mathrm{Pb}-\mathrm{Pb}$ isotopic evidence for the origin of the early Proterozoic Svecokarelian crust in Finland. Geological Survey of Finland Bulletin 337, $52 \mathrm{p}$.

Nironen, M. \& Csongrádi, J., 1984. Characteristics of the Proterozoic porphyry-type $\mathrm{Cu}$ occurrence at Tienpää, the preservation of olivine in the garnet orthoclasite. These features as well as the sharply crosscutting character of the garnet orthoclasite veins suggest that a remnant melt rather than fluids generated the garnet orthoclasite. The relatively low content of $\mathrm{Rb}$ in the host hypersthene granite suggests either that the erosional surface represent a deep section of a differentiated body in which $\mathrm{Rb}$ and other incompatible elements concentrated in the upper part, or that these elements were enriched in the garnet orthoclasite melt.

Acknowledgements. The material of this study was collected and processed during 1980 - 1983 when the authors worked as researchers in the Porphyry Project at the Department of Geology, University of Helsinki. The authors are grateful to Dr. O. Kouvo and the staff of the Isotopic Unit of the Geological Survey of Finland for providing the age data. Moreover, the authors are grateful to Dr. P. A. Nurmi who assisted in the field work.
Halsua, western Finland. Bulletin of The Geological Society of Finland 56, 89-97.

Nurmi, P. A., 1985. Lithogeochemistry in exploration for Proterozoic porphyry-type molybdenum and copper deposits, southern Finland. Journal of Geochemical Exploration 23, 163-191.

Nurmi, P.A., Front, K., Lampio, E. \& Nironen, M., 1984. Svecokarelian porphyry-type molybdenum and copper occurrences in southern Finland: their granitoid host rocks and lithogeochemical exploration. (in Finnish, with an English summary) Geological Survey of Finland, Report of Investigation $67,88 \mathrm{p}$.

Oivanen, P. \& Eskola, L., 1972. Selostus $\mathrm{MoS}_{2}$-malmiaiheen johdosta suoritetuista tutkimuksista Viitasaaren Lahnasilla vv. 1969-1971. (in Finnish) Unpublished report, Geological Survey of Finland.

Received January 23, 1992

Revision accepted April 4, 1992 